\title{
EARNINGS FRAUD AND FINANCIAL STABILITY
}

\author{
Ahmad Abbas \\ Universitas Fajar \\ mad_mad.abaz@yahoo.co.id
}

\begin{abstract}
ARTICLE INFORMATION
Article history:

Received July 30, 2016

Revised Nov 12, 2016

Accepted May 18, 2017

JEL Classifications

D73; D82; G32

Key Words:

Earning Frauds;

Financial Stability;

Financial Distress.

DOI:

ABSTRACT

Earnings can be the goal for firms which desire to commit financial fraud. This study is propounded to show fraudulent earnings reporting and its relationship with the company's financial stability. The samples used in this study are manufacturing firms listed on the Indonesian Stock Exchange during the period of 2010-2013. The data consisting of financial statements are processed using descriptive statistics, and the hypotheses are tested using logistic regression. The results of this study reveal that 22 financial statements are indicated earnings fraud. Of all the financial statements, 68 percent suffers from financial distress. This study shows that the firms with the improved financial stability tend to restrain themselves from committing earnings fraud. This study also finds that the firms which experience financial distress have a greater incentive to commit the fraud.
\end{abstract}

10.21532/apfj.001.17.02.01.010

\section{INTRODUCTION}

Fraudulent financial reporting has become an issue for years and attracted many researchers to explore its determinants. The increasing number of companies sanctioned by Financial Services Authority (hereinafter referred to as OJK) has encourage some researchers in Indonesia to contribute empirically (Mardiana, 2015; Nugraha and Henny, 2015; Puspatrisnanti and Fitriany, 2014; Putra and Fitriany, 2015; Ratmonoet al., 2014; Sukirman and Maylia, 2013). Inconsistency continues to emerge in line with the limited number of cases disclosed. Therefore, some researchers have not been able to focus on which financial reporting referred to as fraud because the sanctions for the rule violation imposed by OJK are specified by some cases only such as late submission of financial statements, of financial data misstatements and unrevised, stock trading manipulation, and other financial 
information. Some of them are trying to emphasize the violations on the basis of the misstatements in financial reports or in the presentation and the disclosure of financial reports, but their outlook still provides the same study design and they just add different variables so that the results continue to produce inconsistencies between other studies.

In financial fraud, earnings will always be the target for opportunists to set the pattern through income-increasing / decreasing or referred to as earnings management ( $\underline{\mathrm{Scott}}$, 2009), or even the earnings is manipulated to make the performance of the financial statements look good, such as the case of Enron (Warshavsky, 2012). Manipulation through the distortion of earnings is a pattern that becomes their focus (Ahmed and Naima, 2016; Anh and Linh, 2016; Dalnial at al., 2014; Kaur at al., 2014; Mahama, 2015; Omar at al., 2014; Paolone and Magazzino, 2014). Their findings appear to be more useful as a medium of knowledge. The model may be considered modest, but their perspective encourages such studies to be conducted in Indonesia. In some countries, researchers are increasingly enthusiastic to reveal a total inclination of corporate financial fraud practices with forensic tools using the formula of Beneish M-Score and digital analysis of Benford's Law (Warshavsky, 2015). By using forensic analysis of M-score as the contributions of some previous studies, this study aims to reveal fraudulent financial reporting, particularly on the corporate earnings.
Furthermore, the awareness of the influence of financial stability experienced by a company has allow the company to depressively conduct earnings fraud practices. Therefore, this study needs to prove and analyze the relationship between the two. Some previous studies are less contributive to prove the relationship between the two under the framework of the theory of fraud (Halioui and Chellouf, 2013; Skousen at al., 2009; Suyanto, 2009; Tiffani and Marfuah, 2015). In general, companies with good financial stability tend to avoid from the pressure so that they control themselves not to commit fraudulent practices, while the companies with financial distress tend to have a greater pressure to commit fraudulent practices. Therefore, this study seeks to analyze the existence of financial stability in affecting fraud. Since the concept of fraud was modeled, it has been encouraging scientists to continue to innovate, and thus inconsistencies continue to arise. Finally, their findings seem to be rhetoric. Through this study, the results are expected to encourage the creation of rhetoric that is consistent with the theories and practices related to fraud.

The main purpose of the study is to reveal the financial statements that contain manipulative earnings (fraud). In addition, this study also seeks to classify companies constructively based on the tendency of their financial stability so that the next purposes are needed by testing the effect of financial stability on earnings fraud.

This study attempts to explore the fraudulent practices by highlighting the 
company's earnings in the financial statements. This study also provides extra contribution to the financial study relating to fraud. First, the findings of this study are used as the media by presenting scientific evidence, in which some manufacturing companies that experience financial difficulties are likely to engage in fraudulent practices by providing good-looking financial statements. Second, the results of this study also become persuasive signal addressed to stakeholders, particularly investors and creditors, due to the discovery that the companies that experience financial difficulties have greater possibility to commit financial fraud. Third, the results of this study provide universal contributions to science in the study of fraud. When faced with the tendency of financial stability, financial distress turns out to be a situational motive for companies to commit financial reporting fraud.

Next, this study is presented in four parts. Theoretical framework and hypothesis development are presented in part two, while research methods are presented in part three, and analysis and discussion are in part four. This study is terminated at the conclusion in part five accompanied by the implications and limitations of the study

\section{THEORETICAL FRAMEWORK AND HYPOTHESIS DEVELOPMENT}

\section{Theory of Fraud}

This theory evolves after Cressey (1953), in the study of social psychology, initiates a model that explains three causal factors of fraud. The model is described in the terms of the three angles, commonly known as fraud triangle, in which each represents pressure, opportunity, and rationalization. This model explains fraud in general and has become a useful tool for public accountants to understand the risk factors of financial fraud. In 2002, the American Institute of Certified Public Accountants (AICPA) issued a statement on auditing standards, namely SAS No. 99. The aim is to improve the effectiveness of the auditor in detecting fraud through assessment of risk factors of corporate fraud. The standard is based on the framework of fraud triangle model. On its development, Albrect at al. (1984) introduces the 'fraud scale model' which considers that rationalization is difficult to be measured so that personal integrity is more appropriate to replace it. Integrity emphasis on the ethical behavior of a person in decision-making.

Based on the framework of fraud triangle model, the development of financial fraud model began to have more attention. Wolfe and Hermanson (2004) add one more angle, capability, and then the shape changes into diamond, or "fraud diamond theory". They believe that the three determinants of financial fraud must be supported by the expertise and competence, or capability. Abdullahi at al. (2015) finds that fraud triangle and fraud diamond provide the understanding of fraud theory.

Financial fraud model continues to evolve (Dorminey at al., 2012) and even Kassem and Higson (2012) attempt to mediate the existing variables of fraud model and create new fraud triangle model by considering the viewpoint 
of the previous initiators, such as opportunity which is adopted from the fraud triangle model, motivation which is adopted from the MICE model (Money, Ideology, Coercion, and Ego), capability which is adopted from fraud diamond, and fraud scale with its personal integrity. The emergence of various innovations in the design of fraud model will not be separated from Cressey (1953) ) as the pioneer of the fraud model.

\section{Earnings Fraud and Financial Stability}

Since the Enron case that manipulatively reported an increase its earnings from 13.3 billion dollars in 1996 to 100.8 billion dollars in 2000 with estimated revenue growth of 151 percent, Warshavsky (2012) attempted to detect Enron's earnings quality which had been distorted from its actual earnings using the M-score model of Beneish (1999). The result of the distortion was 1.89 , which is far from the standard of -2.22 . This means that the firm performed extreme earnings manipulation. Enron itself was regarded as a successful and innovative energy company in the United States at that time, because it always appeared with impressing financial statements.

The information provided in the financial statements is very crucial for the users (Ozcan, 2016). Investors are one of the main targets for increasing company value. They would rely on information related to the statement of financial position (Vlad at al., 2011). Income settings may become an initiative for the company. Delaying recognition of expenses, utilizing the recognition of receivables or depreciation rates, and other accounting tricks encourage the management to be creative in setting the financial performance display, because the company's financial statements presented are the result of accounting methods. It might be simpler to do than performing fictitious recording. However, if the financial difficulty occurs for several periods, it can be done.

The tendency of financial stability gives the companies a pressure to get involved in fraud. Vona (2008) states that the motive to commit fraud is often associated with personal or corporate pressure. If a corporate, with a threatened financial stability, should perform a good reputation, the external pressure becomes a proper motive for committing fraud (Kassem and Higson, 2012). Undeniably, Enron also faced financial difficulties and the external pressures had encouraged the company to commit financial fraud.

Several previous studies have attempted to examine the relationship between financial stability and fraud. What were hypothesized, by seeing the positive influence of the pressure of financial stability tendency on fraud, is not consistent with the findings (Skousen at al., 2009). Their findings are not in line with the expectations of the ideal concept of fraud so that there is inconsistency from one study to another (Nugraha and Henny, 2015; Oktaviani at al., 2014; Putra and Fitriany, 2015; Sukirman, 2013; Tiffany and Marfiah, 2015).

Empirically, fraud theory may explain the relationship between financial stability and fraud. Wolfe and Hermanson (2004) argue that although the pressure can emerge along with the 
opportunity and rationalization, the capability can be an additional element. This study agrees with such view. With the capability, fraud will be obscured well by the external users. However, this capability should not be an angle that aligns with the pressure, opportunity, and rationalization. It automatically always attaches to each of the three angles of the fraud triangle model. Based on the theoretical framework of fraud, this study will rely on the angle of pressure. The pressure can emerge along with the opportunity and rationalization. The emergence of pressure allows the opportunity sought by rationalization to provide goodlooking financial statements (manipulation).

Furthermore, the tendency of financial stability is likely to cause external pressure. The external pressure, as proxied by Kassem and Higson (2012) in fraud triangle model, becomes the dominant motive to commit fraud. In his study, Ozcan (2016) reveals empirically that the decline in financial performance encourages financial fraud. It can be understood that when performance is good and growing, a company tends to avoid from the pressure. The companies, with better financial stability, will provide a negative effect on earnings fraudulent practices. In other words, the companies with good financial stability will ideally be able to prevent themselves from manipulating earnings in their financial statements. The existence of negative influence of good financial stability on earnings fraud is the expected results in this study.

H1. The better the financial stability of a company, the lower the tendency of the company to commit earnings fraud
Conversely, poor financial conditions tend to encourage management to take unethical action to manipulate the performance of its financial position report in order to look good (Bell at al., 1991). But so far, Halioui and Chellouf (2013), Mardiana (2015) empirically have revealed that financial distress through the Z-score has a negative influence on fraud. Whereas, when a company faces financial distress, the company will positively be encouraged to commit fraud. Therefore, this study still agrees that the companies facing financial difficulties would ideally be more motivated to commit fraud. As a result, the positive effect will be generated.

When a company experiences distress, the possibility to commit fraud will increase (Rezaee, 2005). Beasley (1996) states that the company experiencing financial distress will more likely to manipulate its finance so that the financial condition existing in the financial statement looks good. In line with the statement, Dichev at al. (2016) reveals that the general reasons to perform earnings misrepresentation is a desire to influence the stock. Poor quality of reported earnings will certainly affect the stock price and the cost of capital (Dichev at al., 2013). When faced with financial distress, the pressure to make earnings quality look good is greater. In his study, Arshad at al. (2015) reveals that the company that experiences financial distress has more incentive or encouragement to commit earnings fraud than the company that does not experience financial distress. Understanding that, the company experiencing distress tends to have greater impetus to commit fraud than the stable company. In the circumstances, not 
all companies seem stable. They have their own tendencies to run the business, whether stable, fluctuating, or distress during the period. This study estimates that there are different incentives in earnings fraud conducted between the companies experiencing distress and those that are stable. A strong motive tends to arise when facing financial distress. Therefore, fraud is committed more by the companies that experience financial distress than those that have stable financial condition. Financial distress is expected to show a positive effect on earnings fraud.

H2. The pressure to commit earnings fraud is experienced more by the companies during the distressed condition than during the stable condition.

A strong motive to commit fraud is also possibly experienced by companies with unstable financial condition. Companies with unstable financial condition are expected to be different from the those with stable financial condition. Fluctuated financial condition enables greater differentiation of fraud experienced by unstable companies. Thus, the companies with unstable financial condition are encouraged to commit earnings fraud than those with stable financial condition. Unstable financial condition is expected to show a positive effect on earnings fraud.

H3. The pressure to commit earnings fraud is experienced more by companies during unstable financial condition than during stable financial condition.

\section{RESEARCH METHOD}

\section{Sample}

This research is a quantitative research which analyzes financial reporting data and conducts hypothesis testing. The research setting is the field setting using the company's financial statements as the analysis unit. The data of companies' financial statements, as the samples, obtained from the Indonesian Capital Market Directory (ICMD) and the general publication of the Indonesia Stock Exchange (BEI) are collected using documentation method. The samples in this study consist of companies listed on the Indonesian Stock Exchange from 2010 to 2013 . There are 87 companies taken as the samples of this study with the criteria as shown in Table 1:

Table 1

Criteria of Sampling

\begin{tabular}{lc}
\hline \multicolumn{1}{c}{ Criteria } & Company \\
\hline Registered subsequently by issuing financial statements $2010-2013$ & 125 \\
The financial statements do not expire on December 31 & $(4)$ \\
The financial statements use foreign currency & $(24)$ \\
Incomplete data information & $(10)$ \\
\hline Total & $\mathbf{8 7}$ \\
\hline Number of data observation & $\mathbf{2 6 1}$ \\
\hline
\end{tabular}

Source: Processed data, 2016 
The observation period of this research is three years from 2011 to 2013. The data of 2011 is required to measure the earnings fraud $(\mathrm{t}-1)$.

\section{Research Variables}

The variables of this study are earnings fraud and financial stability. Earnings fraud is the earnings that contain fraud in financial statements, in which the reported earnings deviate from actual earnings. The earnings look qualified in the eyes of external users of the company. The standard to indicate earnings fraud is M-score which is greater than -2.22. The size of M-score in this study is measured using $\mathrm{M}=-6.065+0.823 \mathrm{DSRI}+0.906 \mathrm{GMI}+0.593 \mathrm{AQI}+0.717 \mathrm{SGI}+0.107 \mathrm{DEP}$

In addition, indicators and benchmark of fraud are presented in Table 2 below.

Table 2

Indicator of Modified M-Score

\begin{tabular}{|c|c|c|}
\hline Panel A. Index Size & & \\
\hline DSRI (Days Sales in Receivables Index) & $=$ & $\frac{{\text { (Net Receivable / Sales })_{t}}_{\text {(Net Receivable / Sales })_{t-1}}}{\text { Net }}$ \\
\hline GMI (Gross Margin Index) & $=$ & $\begin{array}{l}\left(\underline{\text { Sales-COGS / Sales })_{t-1}}\right. \\
(\text { Sales-COGS / Sales })_{t} \\
\underline{1-(\text { Current Assets / Net Fixed Assets } /}\end{array}$ \\
\hline AQI (Asset Quality index) & $=$ & $\begin{array}{l}\text { Total Assets })_{t} \\
1 \text {-(Current Assets / Net Fixed Assets / } \\
\text { Total Assets })_{t-1}\end{array}$ \\
\hline SGI (Sales Growth Index) & $=$ & $\underline{\text { Sales }}_{t}$ \\
\hline DEPI (Depreciation Index) & $=$ & 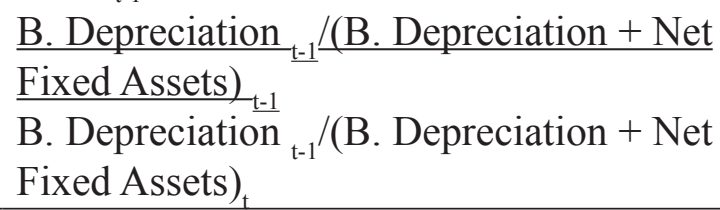 \\
\hline
\end{tabular}

the formula of Beneish (1999) with five ratios that have been modified since some researchers (Kaur at al., 2014; Mavengere, 2015; Paolone, 2014) have considered that only five ratios of M-Score that generate significant result. In previous studies, Roxas (2011) confirms that the M-Score, with five ratios, can indentify earnings manipulation more accurately than the seven ratios. If the M-Score is above -2.22 , the company is indicated to have committed earnings fraud, with value of 1 , and 0 is in contrary. The formula of M-score is presented as follows: 


\section{Panel B}

Benchmarks

\begin{tabular}{lc}
\hline \multicolumn{1}{c}{ Ratio } & Fraudster Mean Index \\
\hline DSRI (Days Sales in Receivables Index) & 1.46 \\
GMI (Gross Margin Index) & 1.19 \\
AQI (Asset Quality index) & 1.25 \\
SGI (Sales Growth Index) & 1.60 \\
DEPI (Depreciation Index) & 1.07 \\
\hline
\end{tabular}

Source: Beneish (1999), Warshavsky (2015)

The measurement of financial stability is conducted using Z-score of Altman (1968). Z-score model provides the best predictions only for modeling manufacturing companies (Chouhan at al., 2014). In Z-score model, the high value means that the company is in the safe zone.

$\mathrm{Z}=1.2 \mathrm{X} 1+1.4 \mathrm{X} 2+3.3 \mathrm{X} 3+0.6 \mathrm{X} 4+1.0 \mathrm{X} 5$

Tabel 3

\section{Z-Score Indicator}

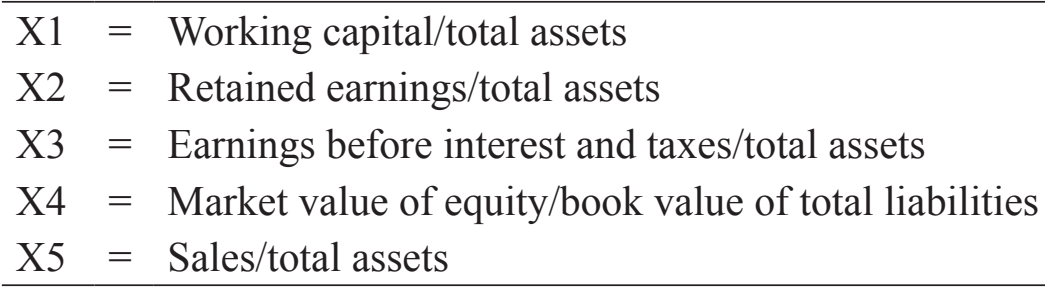

Source: Altman (1968)

The results of Z-Score model is categorized into three zones. $Z>2.99$ is the safe zone, $1.81>Z>2.99$ is the gray zone, and $Z>1.81$ is the distress zone. Previous study conducted by Chouhan at al., (2014) utilizes Z-score for reviewing the company's financial stability in each period by setting $Z>2.99$ with the safe zone is considered a safe condition, $1.81>\mathrm{Z}>$ 2.99 with gray zone is considered stable, and $\mathrm{Z}$ $>1.81$ with the distress zone is considered to be headed for bankruptcy. Actually, the company's financial stability is more representatively reviewed from the tendency for some periods, and not in that period alone is said to be stable. Understanding such condition, this study reviews the company's financial stability by utilizing Z-Score measurement and classifies based on the zone and then establishes the company representatively with the category of stable or not. The tendency of the Z-Score owned by companies in each period must be obtained in advance. By relying on the cutoff of Z-score of Altman (1986), this study establishes that the company with a Z-score below $1.81(Z<1.81)$ respectively during the observation period is categorized financial distress. If not, in which the company within a certain period (fluctuated), it is categorized unstable, whereas if the company successively has $Z>1.81$, it is categorized stable. These 
categories are measured in dummy (k-1) with the number of $\mathrm{k}$ is three groups. The excluded group is stable given the value of 0 , while unstable and distress are the included group and given the value of 1 .

Since the earnings which are indicated manipulative influence stock returns (Beneish at al., 2013) in which the earnings of probability are related to stock returns (Chan at al., 2006; Larson at al., 2011), this study utilizes stock return as control variables. Stock returns are obtained from the difference between the stock price of the current period and the previous $\operatorname{period}\left(\mathrm{P}_{\mathrm{t}}-\mathrm{P}_{\mathrm{t}-1} / \mathrm{P}_{\mathrm{t}-1}\right)$.

\section{Data Analysis Technique}

Data are analyzed based on the objectives of the study using logistic regression. Associate degree of Cramer is used as a follow-up analysis to look at the robustness of the results of the hypothesis. The degree is also used to test the motive force of financial stability in encouraging earnings fraud. To test the hypothesis, logistic regression is used. Equation model to test the hypothesis 1 is as follows.

$$
\text { FRAUD }=\alpha+\beta_{1} \operatorname{StFIN}+\beta_{2} \text { RETURN }+\varepsilon
$$

Equation model to test hypothesis 2 and 3 is as follows:

FRAUD $=\alpha+\beta_{1}$ DISTRESS $+\beta_{2}$ INSTABLE + $\beta_{3}$ RETURN $+\varepsilon$

Table 4

Description of the Proxy of Equation Variable

\begin{tabular}{ll}
\hline FRAUD & $=$ Earnings fraud of M-Score \\
StFIN & $=$ Financial stability of Z-Score \\
INSTABLE & $=$ Fluctuated financial condition with dummy of the variable of stable \\
DISTRESS & $=$ Financial difficulty with dummy of the variable of stable \\
RETURN & $=$ Stock returns based on actualization
\end{tabular}

Source: Author

\section{DATA ANALYSIS AND DISCUSSION Description of the Data}

Table 5 shows the description of earnings fraudulent practices of the year 2011- 2013. In panel A, M-score, as a forensic tool to detect fraud, indicates 22 financial statements are above the value of -2.22 . The companies that manipulate their earnings tend to occur every year. In fact, during the process of observation and input of the data, there are two companies with the financial statements that produce M-score above -2.22 for two years. 
Table 5

Descriptive Statistics of Earnings Fraud

Panel A. M-Score

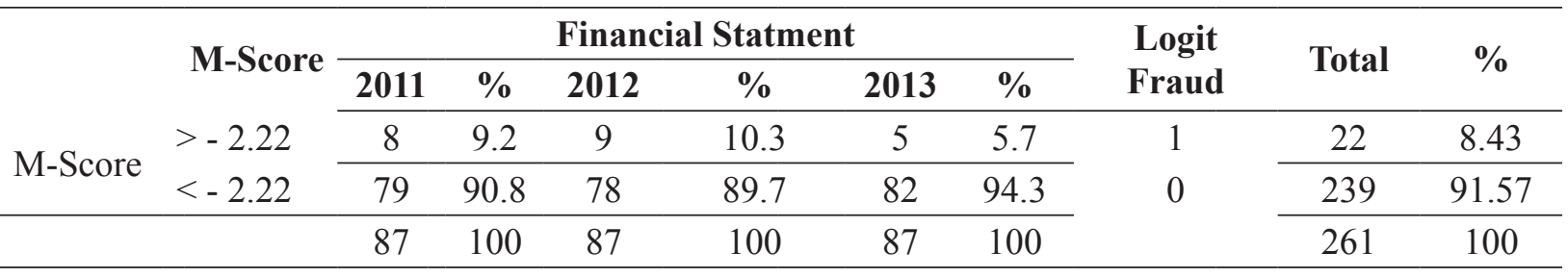

Panel B. Logit of earnings fraud

\begin{tabular}{lccccc}
\hline \multirow{2}{*}{ FRAUD } & Fraud & $\mathbf{N}$ & & Mean & Std. Dev \\
\cline { 2 - 6 } & 1 & & 22 & 1.31 & 1.96 \\
\cline { 2 - 6 } & 0 & 239 & -3.05 & & 0.13 \\
\end{tabular}

Source: Processed Data, 2016

Having obtained 22 financial statements containing earnings fraud, this study analyzes each index of earnings fraud shown in Table 6. The average sample companies, that produce M-score above -2.22 , have an index above fraudster main index. The index indicates that there is an increase which is not comparable in accounts receivable to sales. In addition, the average sample companies show high gross margin index above the index of fraud. This index indicates that the companies have experienced a decrease in gross margin. The amount of pressure to improve their financial performance encourages them to manipulate through margin index. In addition, the average sample companies seek to encourage the growth of sales. There are companies that have a very large index indicated on SGI maximum index of 3.94. It can be that the company is very depressed to seek ways to improve its performance, such as by shifting revenue recognition. If there is an abnormal rise in sales, it is possible because the company has shifted the revenue recognition to the next period.

Table 6

Descriptive Statistics of Earnings Fraud Index

\begin{tabular}{lcccccc}
\hline \multicolumn{1}{c}{ Ratio } & $\begin{array}{c}\text { Fraudsters } \\
\text { Mean Index }\end{array}$ & N & Mean & Median & Min & Max \\
\hline $\begin{array}{l}\text { DSRI(Days Sales in Receivables } \\
\text { Index) }\end{array}$ & 1.46 & 22 & 1.93 & 1.39 & 0.38 & 10.55 \\
GMI (Gross Margin Index) & 1.19 & 22 & 4.41 & 1.51 & -1.36 & 46.91 \\
AQI (Asset Quality index) & 1.25 & 22 & 1.00 & 1.00 & 1.00 & 1.00 \\
SGI (Sales Growth Index) & 1.60 & 22 & 1.41 & 1.20 & 0.84 & 3.94 \\
DEPI (Depreciation Index) & 1.07 & 22 & 1.03 & 0.97 & 0.04 & 3.78 \\
\hline
\end{tabular}

Source: Processed Data, 2016 
In the shrinkage index, some sample companies have altered the estimated economic life. Overall, it is only the asset quality index that is still maintained. There is no reduction in the asset quality of the sample companies. Warshavsky (2012) states that the asset quality which is greater than 1 or close to fraud index indicates that the company is improving its suspension costs or intangible assets, and is encouraged to commit earnings manipulation. Asset quality index is still maintained on the sample of companies because they are not indicated abnormal indexes.

Table 7

Descriptive Statistics of Financial Stability

Panel A. Z-Score

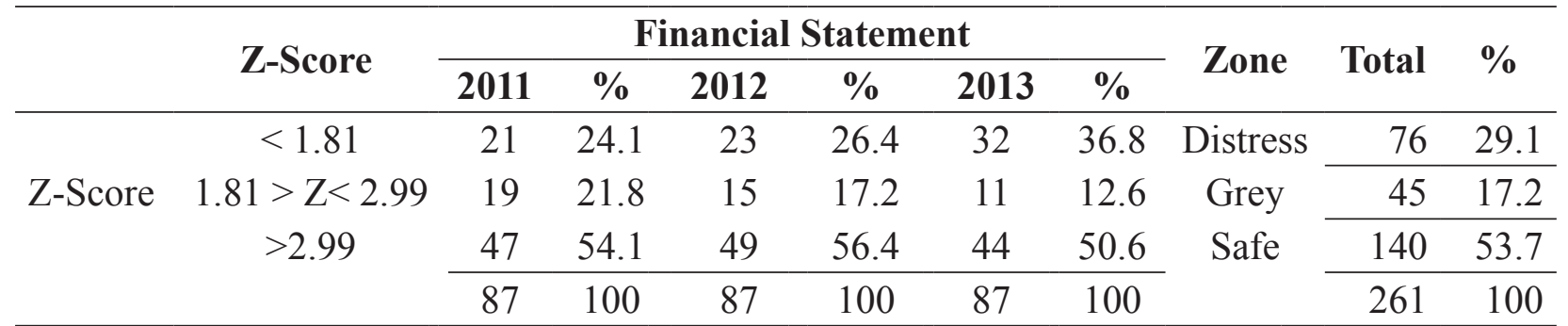

Panel B. The companies with financial distress that commit earnings fraud

\begin{tabular}{lcccc}
\hline & Threshold & Group & N & \% \\
\hline Fraud & $<1.81$ & Distress & 15 & 68.2 \\
\hline & $>1.81$ & Non distress & & 7 \\
\hline & & 22 & 31.8 \\
\hline
\end{tabular}

Panel C. Financial Stability for period 2011-2013

\begin{tabular}{llccc}
\hline & $\begin{array}{c}\text { Firms' Financial } \\
\text { Stability }\end{array}$ & N & Mean & Std. Dev \\
\hline Group & Distress & 12 & 0.13 & 0.34 \\
& Unstable & 30 & 0.34 & 0.47 \\
& Stable & 45 & 0.51 & 0.50 \\
\cline { 2 - 5 } & & 87 & & \\
\hline
\end{tabular}

Source: Processed Data, 2016

Furthermore, Table 7 shows the description of the financial stability from 2011 to 2013. In Panel A, 76 financial statements show the Z-score below 1.81 with an indication of distress. The companies facing financial distress continue to increase every year. In fact, there are 15 financial reports indicated having M-score above -2.22 (Panel B). This shows that $68.2 \%$ companies experiencing financial distress commit earnings fraud. The remaining portion of $31.8 \%$ does not commit fraud. Based on the observations, the sample firms that are indicated distress and not involved in fraud have a Z-score almost close to nondistress zone so that the pressure experienced is not so great. In addition, pressure may arise along with the opportunity and rationalization. They may be at a pressure that does not have 
a great opportunity to get involved in fraud (on robust governance) and avoid from strong rationalization.

Panel $\mathrm{C}$ in Table 7 above shows the financial stability category for three years. Of the 87 companies, the average sample companies experience financial stability at $51.7 \%$. Nevertheless, there are 12 companies that are consistently experiencing financial distress.

Tabel 8

Descriptive Statistics of Variables

\begin{tabular}{|c|c|c|c|c|c|c|c|}
\hline \multirow{2}{*}{ Variable } & \multicolumn{2}{|c|}{ Mean } & \multirow{2}{*}{$\begin{array}{c}\text { Mean } \\
\text { Difference }\end{array}$} & \multicolumn{2}{|c|}{ Std. Dev } & \multirow{2}{*}{$\mathbf{T}$} & \multirow{2}{*}{ Sig } \\
\hline & Fraud & Nonfraud & & Fraud & Nonfraud & & \\
\hline StFIN (financial stability) & 1.47 & 5.96 & -4.49 & 2.95 & 14.76 & -3.93 & 0.00 \\
\hline RETURN (stock return) & 0.37 & 0.17 & 0.19 & 0.98 & 0.79 & 0.921 & 0.36 \\
\hline
\end{tabular}

Source: Processed Data, 2016

In Table 8, the descriptive statistics of variables with univariate test results show differences in the characteristics of the two groups of fraud and non-fraud. The mean value of the variable of StFIN in fraud group is smaller than non-fraud group with significance level below $1 \%$. Instead, the variable of RETURN indicates the average value of fraud group is greater than non-fraud group with significance level above $10 \%$.

\section{Hypothesis Testing Results}

In Table 9, model 1 presents the test results of hypothesis 1 (H1). It shows that the variable of StFIN provides negative results with significance level of $1 \%$. The negative influence indicates that the better the financial stability of the company, the more restricted to commit fraud. Thus, $\mathbf{H 1}$ is accepted. When the financial stability is good and growing, the company tends to avoid the pressure.

Table 9

Results of Logistic Regression

\begin{tabular}{|c|c|c|c|c|c|c|c|c|c|c|}
\hline \multirow{2}{*}{ Variable } & \multirow{2}{*}{\multicolumn{2}{|c|}{$\begin{array}{c}\begin{array}{c}\text { Expecte } \\
\text { d }\end{array} \\
\text { Sign } \\
\end{array}$}} & \multicolumn{4}{|c|}{ Model 1} & \multicolumn{4}{|c|}{ Model 2} \\
\hline & & & B & Wald & Sig. & $\operatorname{Exp}(B)$ & B & Wald & Sig. & $\operatorname{Exp}(B)$ \\
\hline Constant & & & -1.534 & 27.314 & $0.000^{* * *}$ & 0.216 & -2.896 & 59.046 & $0.000^{* * * *}$ & 0.055 \\
\hline StFIN & H1 & - & -0.324 & 11.008 & $0.001^{* * *}$ & 0.723 & & & & \\
\hline DISTRESS & $\mathrm{H} 2$ & + & & & & & 1.706 & 10.206 & $0.001^{* * *}$ & 5.507 \\
\hline $\begin{array}{l}\text { INSTABL } \\
\text { E }\end{array}$ & $\mathrm{H} 3$ & + & & & & & 0.224 & 0.160 & 0.689 & 1.251 \\
\hline RETURN & & & 0.202 & 1.125 & 0.289 & 1.224 & 0.101 & 0.272 & 0.602 & 1.106 \\
\hline \multicolumn{11}{|c|}{ N 261} \\
\hline \multicolumn{6}{|c|}{ Overall percentage $\quad 91.6 \%$} & & & & & \\
\hline \multicolumn{6}{|c|}{-2 Log Likehood Block 0} & 150.924 & & & & 150.924 \\
\hline \multicolumn{6}{|c|}{-2 Log Likehood Block 1} & 133.275 & & & & 139.881 \\
\hline \multicolumn{6}{|c|}{$\begin{array}{l}\text { Hosmer } \\
\text { Lemeshow }\end{array}$} & 0.171 & & & & 0.763 \\
\hline \multicolumn{6}{|c|}{$\begin{array}{l}\text { Nagelkerke R Square } \\
* * * \text { Significant at the } 1 \% \text { level }\end{array}$} & 0.150 & & & & 0.094 \\
\hline
\end{tabular}

Source: Processed Data, 2016 
Furthermore, model 2 presents the test results of hypothesis 2 and 3 (H2; H3). H2 shows that the pressure to commit fraud is greater when the company is experiencing financial distress than stable, as indicated by a positive coefficient. Based on the hypothesis test results, the variable of DISTRESS shows positive results, with a significance level of $1 \%$. This means that the encouragement to commit earnings fraud is greater in difficult financial conditions than in stable financial condition. From the odds ratio indicated by $\exp (\mathrm{B})$ in Table 9, the value is the logit coefficient of 5,507 which interprets that the encouragement to commit earnings fraud when the company experiences distress is 5,507 times greater than in stable condition (H2 is accepted). Furthermore, the variable of UNSTABLE shows positive results. The results show that the pressure of earnings fraud during unstable financial condition is 1.251 times as great as in stable financial condition. However, the results do not have an impact. Thus, $\mathbf{H 3}$ is rejected. As a control variable, RETURN appears to have no effect on earnings fraud. This allows the stock returns do not become a decisive motive for companies to get involved in fraud.

\section{Additional Analysis}

For additional analysis, Cramer's V test analysis is required to determine the robustness of the power of encouragement of distress, unstable, and stable condition on fraud. Table 10 shows the power produced by each group in encouraging earnings fraud. The encouragement of group of companies that are in distress condition is 0.233 , the company in unstable condition is 0.017 , and the company in stable condition is 0.146 . This condition indicates that companies that are in distress condition have the highest encouragement. Positive results in the group of distress condition indicate the encouragement to engage fraud, while the groups of stable and unstable condition show encouragement that limit themselves to get involved in fraud.

Tabel 10

Results of Cramer's Association Degree Test

\begin{tabular}{lcc}
\hline \multicolumn{1}{c}{ Group } & Value & Approx Sig. \\
\hline DISTRESS & 0.233 & 0.000 \\
INSTABLE & -0.017 & 0.783 \\
STABLE & -0.146 & 0.018 \\
\hline
\end{tabular}

Source: Processed Data, 2016

\section{Discussion}

Based on the theoretical framework of fraud, the results of this study suggest that the tendency of stability raises the pressure for the company to provide good financial statements based on reality with the value of the M-score below -2.22 and good-looking financial statements with the value of the M-score above -2.22 . Capability is certainly necessary to make the company's financial condition can be reported well in the financial statements, but does not become an additional element as 
disclosed by Wolfe dan Hermanson (2004) in using fraud triangle theory. The relationship between financial stability and fraud is at an angle of external pressure. The results of this study empirically support the conceptual perspective of Kassem dan Higson (2012) that since the company threatened by financial stability should be in a good-looking reputation through the reported earnings, the external pressure becomes the determining motive of fraud. The company that seems to have goodlooking financial statements can produce M-score above -2.22 . The company proved to be influenced by the financial distress.

As mentioned earlier in this study about fraud index of the sample companies, the value is abnormal. The company seeks to improve the company performance by distorting accounts receivable, sales, and load. On the gross margin index (Table 6), the index shows a very high value, four times as high as the index of fraud. This condition indicates the company's gross margin, in real terms, has decreased to the extreme so that the company attempts to distort its gross profit through sales and cost of sales. Warshavsky (2012) states that the decline in the index is associated with the company's prospects. The decline in the index has come under heavy pressure so that the company could improve its financial performance. As a result, the distressed company attempts to provide prospective-looking financial statements.

On the other hand, Arshad at al. (2015) states that the distressed company has greater incentive or encouragement to commit fraud than non-distressed company. This study finds that the pressure to do is 5,507 greater during distress than during stable. If a stable company wants to commit fraud, the distressed company will strive about 51/2 times motivated to do so. Thus, the financial distress has greater effect on earnings fraud than the financial stability. In contrast, the study finds that the difference in pressure between unstable financial condition and stable financial condition has no effect on earnings fraud. The non-existence of the difference is because the companies, as the research samples, which are experiencing financial fluctuation tend to move toward stable zone.

\section{CONCLUSION}

In addition to the elaboration of the theories and concepts of fraud that become the initial consideration to achieve the purpose of study, the research model specification and the data quality are also highly considered in this study to generate inference that could have implications for the outsider in practice and the researchers in academic. The good-looking financial statements allow the outsider stuck with the company's prospects. M-score is able to be a signal to them as a forensic tool for detecting fraud, especially if associated with a Z-score. Both succeed in providing their influence in this study which elaborates the theories and concepts of fraud.

This study has reached its goal to analyze earnings fraud and its relation to financial stability. The success of this study, in relation to earnings fraud, provides a relevance to financial stability. Of the 22 financial statements 
containing earnings fraud, about 68 percent is in the face of distress. The results of this study underline that the pressure, in the viewpoint of the theory of fraud, turns out to be situational. The pressure depends on the tendency of financial stability. The better the company's financial stability, the smaller the possibility to commit earnings fraud. In other words, the more distressed the company, the more inclined to engage in fraud. Distress turns out to have a greater impetus to commit earnings fraud. When the companies are experiencing distress, they are more motivated to commit earnings fraud $5 \frac{1}{2}$ times as great as non-distress.

This study is aware of the company's financial stability that is still in relatively short term so that in 3-5 years ahead there will possibly be changes in financial stability. It becomes the limitations imposed in this study for the purpose of further study.

\section{REFERENCES}

Abdullahi, R, N. Mansor, dan M.S. Nuhu. (2015). Fraud Triangle Theory and Fraud Diamond Theory: Understanding the Convergent and Divergent for Future Research. European Journal of Business and Management, 7(28): 30-37.

Ahmed, T dan J. Naima. (2016). Detection and Analysis of Probable Earnings Manipulation by Firms in a Developing Country.Asian Journal of Business and Accounting, 9(1):59-81.
Albrect, S. K. Howe, dan M. Romney. (1984). Deterring Fraud: the Internal Auditor's Perspective. Institute of Internal Auditors Research Foundation, 1-42.

Altman, E. I. (1968). Financial Ratios, Discriminat Analysis and the Prediction of Corporate Bankruptcy. The Journal of Finance, 23 (4): 589-609.

Anh, N.H,dan N.H. Linh. (2016). The Using the M-score Model in Detecting Earnings Management: Evidence from NonFinancial Vietnamese Listed Companies. Journal of Science: Economics and Business, 32 (2):14-23.

Arshad, R, S.M. Iqbal, dan N. Omar. (2015). Prediction of Business Failure and Fraudulent Financial Reporting: Evidence from Malaysia. Indian Journal of Corporate Governance, 8(1):34-53

Beasley, M.S. (1996). An Empirical Analysis of the Relation between the Board of Director Composition and Financial Statement Fraud.The Accounting Review, 7(4):443-465.

Bell, T., S. Szykowny, dan J. Willingham. (1991). Assessing the Likelihood of Fraudulent Financial Reporting: a Cascaded Logit Approach. Working Paper, KPMG Peat Marwick.

Beneish, M.D. (1999). The Detection of Earnings Manipualtion. Financial Analyst Journal, 24-26. C. M.C. Lee, dan D.C. Nicholas.

(2013). Earnings Manipulation and 
Expected Returns. Financial Analyst Journal, 69(2): 57-82.

Chan, K, L.K.C, Chan, N. Jegadeesh, dan J. Lakonishok. (2006). Eranings Quality and Stock Returns. Journal of Business, 79(3):1041-1082

Chouhan, V, B. Chandra, dan S. Goswani. (2014). Predicting Financial Stability of Select BSE Companies Revisiting Altman Z-Score. International Letters of Social and Humanistic Sciences, 26: $92-$ 105.

Cressey, D. R. (1953). Other People's Money: a Study in the Social Psychology of Embezzlement. Glencoe, Illinois: the Free Press.

Dalnial, H., A. Kamaluddin, Z.M Sanusi, dan K. S. Khairuddin. (2014). Fraudulent Financial Reporting through Financial Statement Analysis. Journal of Advanced Management Science, 2(1):17-22.

Dichev, I, J. R, Graham, C.R, Harvey, dan S. Rajgopal. (2013). Earnings Quality: Evidence from the Field. Journal of Accounting and Economics, 56(2-3):133.

. (2016). The Misrepresentation of Earnings. Financial Analyst Journal, $72(1): 22-35$.

Dorminey, J., A. S. Flemming, M. Kranacher, dan R.A. Riley. (2012). The Evolution of Fraud Theory. Issues in Accounting Education, 27(2): 555-579.
Halioui, K dan C. Chellouf. (2013). The Determinants of Fraudulent Financial Reporting: An Empirical Study in French Companies. Paper presented in Brawijaya International Conference on Accounting and Business (BICAB).

Isa, T. (2011). Impacts and Losses Caused by the Fraudulent and Manipulated Financial Information on Economic Decisions. Review of International Comparative Management, 12(5):929-939.

Kassem, R dan A, Higson. (2012). The New Fraud Triangle Model. Journal of Emerging Trends in Economics and Management Sciences, 3(3): 191-195.

Kur, R, K. Sharma, dan A. Khanna. (2014). Detecting Earnings Management in India. A-Sector Wise Study. European Journal of Business and Management, 6(11):1118.

Larson, C dan R.J, Resutek. (2011). How Does Earnings Quality Affect the Equity Market? An Alternative Measure and a New Perspective. Paper presented in Accounting Seminars, Columbia Business School.

Mahama, M. (2015). Detecting Corporate Fraud and Financial Distress Using the Altman and Beneish Models: the Case of Enron Corp. International Journal of Economics, Commerce and Management, 3(1):1-18

Mardiana, Ana. (2015). Effect Ownership, Accountant Public Office, and Financial Distress to the Public Company Financial 
Fraudulent Reporting in Indonesia. Journal of Economics and Behavioral Studies, 7(2):109-115.

Mavengere, K. (2015). Predicting Corporate Bankruptcy and Earnings Manipulation Using the Altman Z-Score and Beneish M-Score: the Case of Manufacturing Firm in Zimbabwe. International Journal of Management Sciences and Business Research, 4(10):8-14.

Nugraha, N. D.A, dan D. Henny. (2015). Pendeteksian Laporan Keuangan melalui Faktor Resiko. Tekanan, dan Peluang (Berdasarkan Press Release OJK 20082012). e-Jurnal Akuntansi Trisakti, 2(1) $: 29-48$.

Oktaviani, E, G. Karyawati, dan N. Arsyad. (2014). Factors Affecting Financial Statement Fraud: Fraud Triangle Approach. 3rd Economics \& Business Research Festival, 1939-1955.

Omar, N., R.K, Koya, Z. M, Sanuzi, dan N. A, Shafie. (2014). Financial Statement Fraud: A Case Examination Using Beneish Model and Ratio Analysis. International Journal of Trade, Economics, and Finance, 5(2):184-186.

Ozcan, A. (2016). Firm Characteristics and Accounting Fraud: A Multivariate Approach. Journal of Accounting, Finance, and Auditing Studies, 2(2):128144.

Paolone, F dan C, Magazzino. (2014). Earnings Manipulation among the Main Industrial Sectors: Evidence from Italy.
EconomiaAziendale Online, 5(4):253261.

Persons, O.S.(1995). Using Financial Statement Data to Identify Factors Associated with Fraudulent Fianancial Reporting. Journal of Applied Business Research, 11(3): 3846.

Puspatrisnanti, T dan Fitriany. (2014). Analisis Hubungan Manajemen Laba dan Fraud dalam Laporan Keuangan. Makalah pada Simposium Akuntansi Nasional XVII.

Putra, A.D dan Fitriany. (2015). Fraud Triangle (Pressure, Opportunity, and Rationalization) and the Level of Accounting Irregularities in Indonesia. Makalah pada Simposium Akuntansi Nasional XVIII.

Ratmono, D, Y Avrie, dan A, Purwanto. (2014). Dapatkan Teori Fraud Triangle menjelaskan Kecurangan dalam Laporan Keuangan. Makalah pada Simposium Akuntansi Nasional XVII.

Rezaee, Z. (2005). Causes, Consequences, and Deterence of Financial Statement Fraud. Critical Perspective on Accounting, 16: 277-298

Roxas, M. L. (2011). Financial Statement Fraud Detection Using Ratio and Digital Analysis. Journal of Leadership, Accountability and Ethics, 8(4):56-66.

Scott, W.R. (2009). Financial Accounting Theory, Fifth Edition. Pearson Education, Toronto, Canada. 
Skousen, C.J, K. R, Smith, dan C.J, Wright. (2009). Detecting and Predicting Financial Statement Fraud: the Effectiveness of the Fraud Traingle and SAS No. 99. Advances in Financial Economics, 13:53-81.

Sukirman, dan S, P. Maylia. (2013). Model Deteksi Kecurangan Berbasis Fraud Triangle (Studi Kasus pada Perusahaan Publik di Indonesia). Jurnal Akuntansi dan Auditing, 9(2):199-225.

Suyanto. (2009). Fraudulent Financial Statements: Evidence from Statement on Auditing Standard No. 99. Gadjah Mada International Journal of Business, 11(1):117-144.

Tiffani, L dan Marfuah. (2015). Deteksi Financial Statement Fraud dengan Analisis Fraud Triangle pada Perusahaan Manufaktur yang Terdaftar di Bursa Efek Indonesia. Makalah pada Simposium AkuntansiXVIII.

Vlad, M, M. Tulvinschi, dan I. Chirita. (2011). The Consequences of Fraudulent Financial Reporting. TheUSV Annals of Economics and Public Administration, 11(1):264-268.

Vona, L.W. (2008). Fraud Risk Assessment: Building a Fraud Audit Programme. New Jersey: John Wiley \& Sons.

Warshavsky,M.S. (2012). Analyzing Earnings Quality as a Financiak Forensic Tool. Financial Valuation and Litigation Expert Journal, 39:16-20. .(2015).Forensic Tools \& Techniques. Paper Presented to Marryland Association of CPAs, http://macpamedia. org/media/downloads/2015FVS/ Warshavsky_PPT1pp.pdf, accessed June 20, 2016.

Wolfe, D.T, dan D.R. Hermanson. (2004). The Fraud Diamond: Considering the Four Elements of Fraud. The CPA Journal, 3842. 